\title{
MEMORIA
}

УДК [902+904+7] (477) : 069

DOI: https://doi.org/10.33782/eminak2021.1(33).489

\section{ВАЛЕНТИНА КРАПІВІНА ТА ВИСТАВКА «СКАРБИ ПІВДЕННОЇ УКРАЇНИ» У МИКОЛАЄВІ}

\author{
Ірина Вітрик \\ Музей історичних коштовностей України - філіал Національного музею історії України \\ (Київ, Україна) \\ e-mail: vitryk5678@gmail.com \\ ORCID: https://orcid.org/0000-0002-0851-3850
}

У публікації висвітлюються етапи підготовки й особливості проведення масштабного виставкового проекту «Скарби Південної України» (1997 р.) у Миколаӥвському обласному художньому музеї, який було створено на основі колекцій Наукових фондів та Археологічного музею Інституту археології НАН України й Історико-археологічного заповідника «Ольвія». Проект відбувся завдяки спільним зусиллям Валентини Володимирівни Крапівіної та Валерія Анатолійовича Карнауха.

Ключові слова: В.В. Крапівіна, популяризація археологічних знахідок, виставковий проект, Інститут археології НАНУ, Миколаївський обласний художній музей

Популяризація археологічних знахідок $є$ не менш важливою, аніж їх камеральна обробка, вивчення та публікація. Звичайно, публікація матеріалів сприяє популяризації речей, проте відбувається вона, в основному, у наукових виданнях й ознайомитися з ними має змогу досить обмежене коло зацікавленим осіб. Тому у вирішенні даного питання важливими стають різноманітні публічні заходи - проведення виставок, лекцій, презентацій тощо, які передбачають залучення широкої аудиторії. Через це стає актуальним досвід проведення успішних заходів, у ході яких надається безпосередня можливість побачити на власні очі чи почути про артефакти, що розповідають про давню історію України. Одним з таких заходів стала виставка «Скарби Південної України», що проходила у Миколаєві восени 1997 р.

Наприкінці XX ст. Інститут археології Національної академії наук України (далі IA НАНУ), як і вся молода незалежна Україна, переживали не найкращі часи. Установі катастрофічно не вистачало фінансування, припинили роботу бюджетні археологічні експедиції, відбувалось переміщення основних підрозділів інституту з приміщень Видубецького монастиря, який було передано релігійній громаді, до будівлі Інституту гідробіології ІАНАНУ. Все це спричинило безліч організаційних і господарських проблем. I саме в цей час IA НАНУ проводить фактично першу в межах України масштабну археологічну виставку1 із залученням виробів з дорогоцінних металів, ініціатором якої стала Валентина Володимирівна Крапівіна (1950-2013).

\footnotetext{
1 у 1996 р. була проведена виставка предметів з дорогоцінних металів і гальванокопій у музеї Національного банку України в Києві, але зрозуміло, що доступ до неї був обмеженим.
} 
В.В. Крапівіна, як ніхто інший, притягувала до себе надзвичайно яскравих людей. Так сталося, що у середині 90-х років ХХ ст. перетнулися шляхи двох непересічних особистостей - Валентини Володимирівни та Валерія Анатолійовича Карнауха (1959-2014). В.А. Карнаух - одна зі знакових для Миколаєва постатей. Він, зокрема, активно опікувався культурним життям рідного міста, співпрацював з місцевими театром і музеями, був глибоко зацікавлений минулим Миколаївщини та півдня України. Ця зустріч стала народженням, без перебільшення, визначного проекту 3 популяризації давньої історії України. Зараз важко сказати, як саме виникла ідея проведення виставки, але бажання втілити їі у життя стало взаємним.

У 90-і роки XX ст. IA НАНУ, який зберігав у своїх фондах безцінні колекції археологічних артефактів ${ }^{2}$, у тому числі і з дорогоцінних металів, став долучатися до створення самостійних виставкових проектів, але всі заходи відбувалися за межами України. У світі відчувалося зростання інтересу до історії новостворених на уламках СРСР незалежних держав, а Україна володіла величезним історичним і культурним надбанням, у дечому унікальним, презентація якого на виставках не могла не зацікавити відвідувачів. Проте не менший попит на власну незаангажовану історію виник всередині країни. I хоча вже стала доступною низка наукових, науковопопулярних, навчальних видань на історичну тематику позбавлених ідеологічного забарвлення, музейні установи, в яких мав би оперативно подаватися більш об’єктивний погляд на минуле з урахуванням даних обставин, дещо запізнювалися 3 оновленням експозицій, з донесенням такої інформації на широкий загал.

Зазначимо, що 1990-і роки відзначилися також загальною кризою культурного життя, яка стосувалася і музеїв, серед іншого значно знизилася кількість музейних відвідувачів. Загалом, ті часи були важкими в економічному плані, закривалися підприємства, зростало безробіття, значна частина населення України просто фізично виживала, погіршилася криміногенна ситуація тощо.

Саме тому реалізація задуманого В.В. Крапівіною та В.А. Карнаухом проекту виставки стала своєрідним проривом у культурному житті України - як у популяризації здобутків вітчизняних археологів, так і в подачі наданих ІА НАНУ оригінальних знахідок. До того ж здійснювався він не у столиці, не в місті-мільйоннику, а у відносно невеликому обласному центрі України - Миколаєві.

Якщо В.А. Карнаух взяв на себе всі організаційні питання із забезпечення проведення виставки, а це - залучення міської влади (міський голова Миколаєва О.Я. Бердніков погодився стати координатором виставки), організація охоронних заходів під час перевезення й експонування предметів, надання транспорту, пошук дизайнерів, виготовлення спеціальних вітрин, друк супутньої продукції, а головне оплату всіх витрат, то просуванням ідеї по створенню виставки безпосередньо в ІА НАНУ зайнялася В.В. Крапівіна.

Координатором виставки від Інституту археології став його директор академік НАНУ П.П. Толочко. В ІА НАНУ також була утворена робоча група у складі: д.і.н. Д.Н. Козака (1944-2014), ч чл.-кор. НАНУ С.Д.Крижицького (1932-2018), д.і.н. В.Ю. Мурзіна (1951-2019), к.і.н. В.В. Крапівіної та І.С. Вітрик, яка одразу приступила до складання та погодження списків експонатів майбутньої виставки, адже термін на підготовку був досить обмеженим.

\footnotetext{
2 Блажевич Н.В., Бурдо Н.Б., Вітрик І.С. та ін. Колекції Наукових фондів Інституту археології НАН України. Каталог. Київ: Академперіодика, 2007. 356 с., рис., 16 с. табл.
} 
Вище вже йшлося про переїзд установи, тому археологічні колекції IA HAHУ знаходилися у різних локаціях, а приміщення спецсховища, де б мали зберігатися предмети з дорогоцінних металів, тільки облаштовувалося відповідно до вимог за новою адресою. Перераховане значно ускладнювало процес підготовки. Дещо полегшував завдання відбору речей той факт, що у 1996 р. за участі ІА НАНУ була проведена виставка «Кочівники України» у м. Катовіцез, експонати якої були включені до списків миколаївської виставки. Однак концепція нової виставки охоплювала більш широкий хронологічний діапазон, тому додатково до списків включили археологічні матеріали доби бронзи та доповнили ольвійськими знахідками. На цьому етапі проводилося написання текстів науковцями IA НАНУ та уточнення каталожних даних.

Найбільші незручності полягали у тому, що предмети із дорогоцінних металів розділу I (спецсховища) Наукового фонду (НФ) IА НАНУ перебували на тимчасовому зберіганні у фондах Музею історії Києва. Тому будь-яку дію по роботі з інститутськими матеріалами треба було узгоджувати з музеєм, у тому числі процес фотографування експонатів виставки, яку здійснив фотограф з Миколаєва Ю.В. Матвієнко. За координацію роботи з Історико-археологічним заповідником «Ольвія» відповідала В.В.Крапівіна. Не менш важливим стало пакування речей - частина предметів, особливо це стосувалося виробів з кістки, дерева та скла, вимагала особливих умов перевезення, які б перешкоджали їх руйнуванню. Участь у цих роботах брали В.В. Крутілов (1970-2019) та В.І. Назарчук.

Саме з Музею історії Києва (тоді він ще знаходився у Кловському палаці) ящики 3 речами відправлялися на виставку: в центрі Києва, неподалік Міністерства внутрішніх справ України, група миколаївських міліціонерів-автоматників забезпечувала охорону процесу завантаження машин і потім перевезення експонатів до Миколаївського обласного художнього музею імені В.В. Верещагіна. 3 організаторів цінний вантаж супроводжували В.А. Карнаух та І.С. Вітрик. Автотранспорт на трасі рухався в режимі «зелене світло», тому дорога від Києва до Миколаєва разом з зупинками зайняла менше шести годин. Все одно машини доїхали до пункту призначення вже після закриття музею. Ящики були перенесені до однієї з робочих кімнат музею, двері якої опечатали та залишили озброєну охорону, що була в музеї впродовж усієї роботи виставки.

Цікаво відбувалася передача експонатів на тимчасове зберігання до художнього музею, яка тривала декілька днів: щоб потрапити до приміщення з речами чи вийти з нього треба було озвучити черговому міліціонеру пароль («Волга» - «Дунай»), що змінювався щодня. Посиленні заходи безпеки були цілком виправдані. Після оформлення актів передачі речей від ІА НАНУ подальша робота над виставкою контролювалася працівниками музею.

Над художнім оформленням експозиції працювала дизайнерська команда на чолі 3 С.М. Кручиніним. У Миколаєві ще за попередніх часів був створений і діяв дуже потужний осередок Спілки художників і місцеві митці долучилися до оформлення залу виставки (в ньому було відтворено навіть куточок степового ландшафту) та дизайну супутньої друкованої продукції, зокрема, В.О. Бахтов. Своєрідним «обличчям» виставки стала сцена шматування оленя пантерою, яка розташована на верхній частині ритуального

\footnotetext{
${ }^{3}$ Koczownicy Ukrainy (Кочівники України). Katalog wystawy. Katowice: drukarnia archidiecezjalna w Katowicach, 1996. 244 s.
} 
«конусу» (навершя) з Братолюбівського кургану4. Дана композиція була розміщена на обкладинці каталогу (рис. 1) та афішах.

Окремо хочеться сказати про листівки-афішки або флаєри на газетному папері формату A-5, що поширювалися в місті напередодні відкриття та під час роботи виставки (рис. 2). За умов, коли доступ до Інтернету був обмеженим, ця недорога форма масової реклами зіграла позитивну роль в інформуванні про майбутню подію. Текст флаєра був продуманий до дрібниць з правильно розставленими акцентами, наголос робився на наступному: «Вперше в Україні», «Доторкніться до своєї історії, почуйте голоси предків», «146 комплексів, декілька тисяч предметів, 740 30ЛОТИХ РЕЧЕЙ».

Урочисте відкриття виставки «Скарби Південної України» («Сокровища Южной Украины») відбулося напередодні початку їі роботи, від ІА НАНУ на ньому була присутня його дирекція. Вже з 5 жовтня по 5 грудня 1997 р. миколаївці отримали можливість ознайомитися з виробами із глини, каменю, мармуру, кістки, дерева, скла, бронзи, заліза, золота та срібла від XXV ст. до н.е. (ямна культура) до XIV ст. н.е., що розкривали різні аспекти життя та побуту давнього населення Півдня України. Багато оригінальних речей можна віднести до розряду унікальних (черепи епохи бронзи з модельованими глиною обличчями, кіммерійські кістяні прикраси кінської вузди та знаменитий біметалічний суботівський меч, пам'ятки з Ольвії, зброя та прикраси середньовічних кочовиків).

Надзвичайно цікавою була колекція «скіфського золота» V-III ст. до н.е., яка знайомила відвідувачів з високим рівнем виконання прикрас тогочасними майстрами, 3 володінням і застосуванням ними різних технік обробки металу, а також бездоганним художнім смаком наших предків (Братолюбівський курган, Огуз, Соколова Могила). Про особливості одягу скіфів можна було дізнатися з наукових реконструкцій різноманітних типів головних уборів, плаття та взуття (курган біля м. Кам'янкаДніпровська, Тетянина Могила).

Окрім оригінальних артефактів, були представлені надзвичайно якісно виконані сім гальванокопій шедеврів скіфо-античного мистецтва, серед них всесвітньовідома пектораль - чоловіча нагрудна прикраса з Товстої Могили, оригінали яких знаходяться у Музеї історичних коштовностей України - філіалі Національного музею історії України. Деякі археологічні знахідки до того не експонувалися, і відвідувачі виставки побачили їх вперше. Експонати були надані Науковими фондами й Археологічним музеєм ІА НАНУ, а також Історико-археологічним заповідником «Ольвія», який у 2002 р. отримав статус національного. Без перебільшення можна сказати, що у Миколаєві на виставці були представлені предмети, які мають величезну наукову, історичну та художню цінність і які стали надбанням української та світової культури.

Вже на момент відкриття виставки відвідувачам була запропонована ціла низка поліграфічної продукції: афіші, кишенькові календарики з зображенням знакових експонатів, каталог ${ }^{5}, 25$ науково-популярних брошур (ціна кожної була 2 грн.) по давній історії та культурі населення Південної України від провідних вітчизняних археологів, а також видання «Былое украинских степей»6 3 кольоровими ілюстраці-

\footnotetext{
${ }_{4}^{4}$ Кубышев А.И., Бессонова С.С., Ковалев Н.В. Братолюбовский курган. Киев: ПП «Корвін Пресс», 2009. С. 32-70.

5 Козак Д.Н., Крыжицкий С.Д., Мурзин В.Ю. Сокровища Южной Украины. Каталог выставки. Николаев: Изд-во «Возможности Киммерии», 1997. 27 с.

${ }^{6}$ Козак Д.Н., Крыжицкий С.Д., Мурзин В.Ю. Былое украинских степей. Киев-Николаев: Изд-во «Возможности Киммерии», 1997.51 с.
} 
ями. Нагадаємо, що В.А. Карнаух очолював перше у Миколаєві приватне видавничополіграфічне підприємство «Возможности Киммерии», яке і забезпечило випуск усієї друкованої продукції. Більшість текстів не втратила своєї актуальності донині, можливо, лише деякі потребують певних уточнень, чи не єдиний їх недолік з позицій сьогодення - це російська мова видань. Цікаво, в художньому музеї були реалізовані не всі примірники, тому їх пропонували і в інших музеях: Національному історико-археологічному заповіднику «Ольвія», значним попитом брошури користувались у Національному музеї історії України (рис. 3). До речі, музеям, особливо історичним, катастрофічно бракує подібної продукції у вигляді невеликих за обсягом науково-популярних брошур.

У рамках роботи виставки була проведена 3-8 листопада міжнародна наукова конференція «Нові сторінки давньої історії Південної України» («Новые страницы древней истории Южной Украины») науковці змогли особисто відвідати засідання конференції, що проходила в читальному залі Миколаївської обласної бібліотеки імені О. Гмирьова, але серед доповідачів можна згадати відомих учених-археологів Ю.В.Болтрика, Н.О.Гаврилюк, В.М. Зубара, С.В. Махортиха, О.П. Моцю, О.В. Симоненка, С.А. Скорого, О.Є. Фіалко й інших. Серед виступаючих були автори розкопок, знахідки з яких можна було оглянути на виставці, та автори вищезгаданої літератури. Всі бажаючі (вчителі, викладачі, краєзнавці тощо) отримали можливість послухати виступи науковців та особисто 3 ними поспілкуватись, подискутувати, обговорити спірні питання.

Сама виставка пропрацювала два місяці та мала великий успіх у відвідувачів. Зазначимо, що одним з наслідків проведення виставки стало виконання річного плану Миколаївським обласним художнім музеєм імені В.В. Верещагіна по кількості відвідувачів, однак ця цифра не була аж занадто вражаючою. Можливо, через чутки, які поширювалися містом, про дуже дорогі квитки, хоча насправді вартість одного складала 3 грн., що навіть у ті часи було доступно багатьом (в Україні середня зарплатау 1997 р. складала 143 грн.). Звичайно, питання функціонування експозиції, зацікавленості її матеріалами з боку відвідувачів протягом усієї роботи виставки мають висвітлювати безпосередньо співробітники музею.

Успішна виставка - це кропітка робота команди фахівців, об'єднаних однією метою від початку до завершення її роботи, від появи задуму до його практичного втілення. Виставковий проект «Скарби Південної України», який органічно поєднав естетичну та інформативну складові на суто науковому підгрунті, фактично став для IA НАНУ першим публічним досвідом популяризації здобутків цілої групи дослідників Інституту археології НАНУ на широку аудиторію всередині Україні. I ця подія відбулася завдяки реалізації задумів Валентини Володимирівни Крапівіної та Валерія Анатолійовича Карнауха. У рекламному флаєрі виставки було зазначено «Тільки один раз в житті нашого покоління», що повністю відповідає дійсності, адже проведення такого масштабного заходу потребує залучення різнопланових професіоналів і значних коштів. Проте, подібні заходи дозволяють доповнити та розширити відвідувачам виставок свої знання про світ минулого України, спонукають по іншому подивитися на охорону пам'яток культурної спадщини, формують історичну свідомість, виховують почуття патріотизму та гордості за здобутки предків, якби пафосно це не звучало.

\footnotetext{
7 Новые страницы древней истории Южной Украины. Тезисы междунар. конф. Николаев: МП «Возможности Киммерии», 1997. 48 с.
} 


\section{REFERENCES}

Blazhevych, N.V., Burdo, N.B. \& Vitryk, I.S. etc. (2007). Kolektsii Naukovykh fondiv Instytutu arkheolohii NAN Ukrainy. Kataloh [Scientific Funds' Collections of the Institute of Archaeology National Academy of Sciences of Ukraine. Catalogue]. Kyiv: Akademperiodyka [in Ukrainian].

Koczownicy Ukrainy. Katalog wystawy (1996). Katowice: drukarnia archidiecezjalna w Katowicach [in Polish].

Kozak, D.N., Kryzhitskii, S.D. \& Murzin, V.Yu. (1997). Byloe ukrainskikh stepei [The Past of Ukrainian Steppes]. Kiev-Nikolaev: «Vozmozhnosti Kimmerii» [in Russian].

Kozak, D.N., Kryzhickii, S.D. \& Murzin, V.Yu. (1997). Sokrovishcha Yuzhnoi Ukrainy. Katalog vystavki. [Treasures of Southern Ukraine. Exhibition Catalog]. Nikolaev: «Vozmozhnosti Kimmerii»[in Russian].

Kubishev, A.I., Bessonova, S.S. \& Kovalev, N.V. (2009). Bratoliubovskii kurgan [Bratolyubovsky burial mound]. Kiev: PP «Korvin Press» [in Russian].

Novye stranitsy drevnei istorii Yuzhnoi Ukrayiny (1997). Abstracts of Papers. Nikolaev: MP «Vozmozhnosti Kimmerii» [in Russian].

\section{Iryna Vitryk}

(Museum of Historical Treasures of Ukraine - branch of the Historical Museum of Ukraine, Kyiv, Ukraine)

e-mail: vitryk5678@gmail.com

ORCID: https://orcid.org/0000-0002-0851-3850

\section{Valentyna Krapivina and Exhibition 'Treasures of Southern Ukraine' in Mykolaiv}

In the autumn of 1997, a large exhibition project 'Treasures of Southern Ukraine', organically combining aesthetic and informative components, was held in Mykolaiv, as the realization of Valentyna Volodymyrivna Krapivina and Valerii Anatoliiovych Karnaukh ideas.

The exhibition which took place in the premises of Mykolaiv Regional Art Museum named after V.V. Vereshchahin showed the materials of the Scientific Funds and the Archaeological Museum of the IA NASU and the National Historical and Archaeological Reserve 'Olbia'. For two months the residents of Mykolaiv had an opportunity to get acquainted with archeological finds dated between the $25^{\text {th }}$ century BCE (pit culture) and the $14^{\text {th }}$ century CE, which uncovered various aspects of life and everyday activities of the ancient population of the South of Ukraine. Visitors of the exhibition were offered a number of printed products, in particular, popular science publications on the ancient history and culture of the southern Ukraine population written by leading Ukrainian archaeologists.

An international scientific conference was held within the framework of the exhibition, the admission to the meeting of which was free, so everyone was able not only to listen to the speeches of the scholars but also to communicate with them in person.

The exhibition 'Treasures of Southern Ukraine' was in fact the first public, very interesting and successful experience of popularizing directly in Ukraine not only 'practical' achievements in the form of finds-exhibits, but also scientific ones in the form of popular science publications texts and conference speeches of the Institute of Archeology of NASU scholars.

Keywords: V.V. Krapivina, popularization of archeological finds, exhibition project, Institute of Archeology of NASU (IA NASU), Mykolaiv Regional Art Museum (MOHM) 


\section{Cokpobum, \\ Южной Украшны}

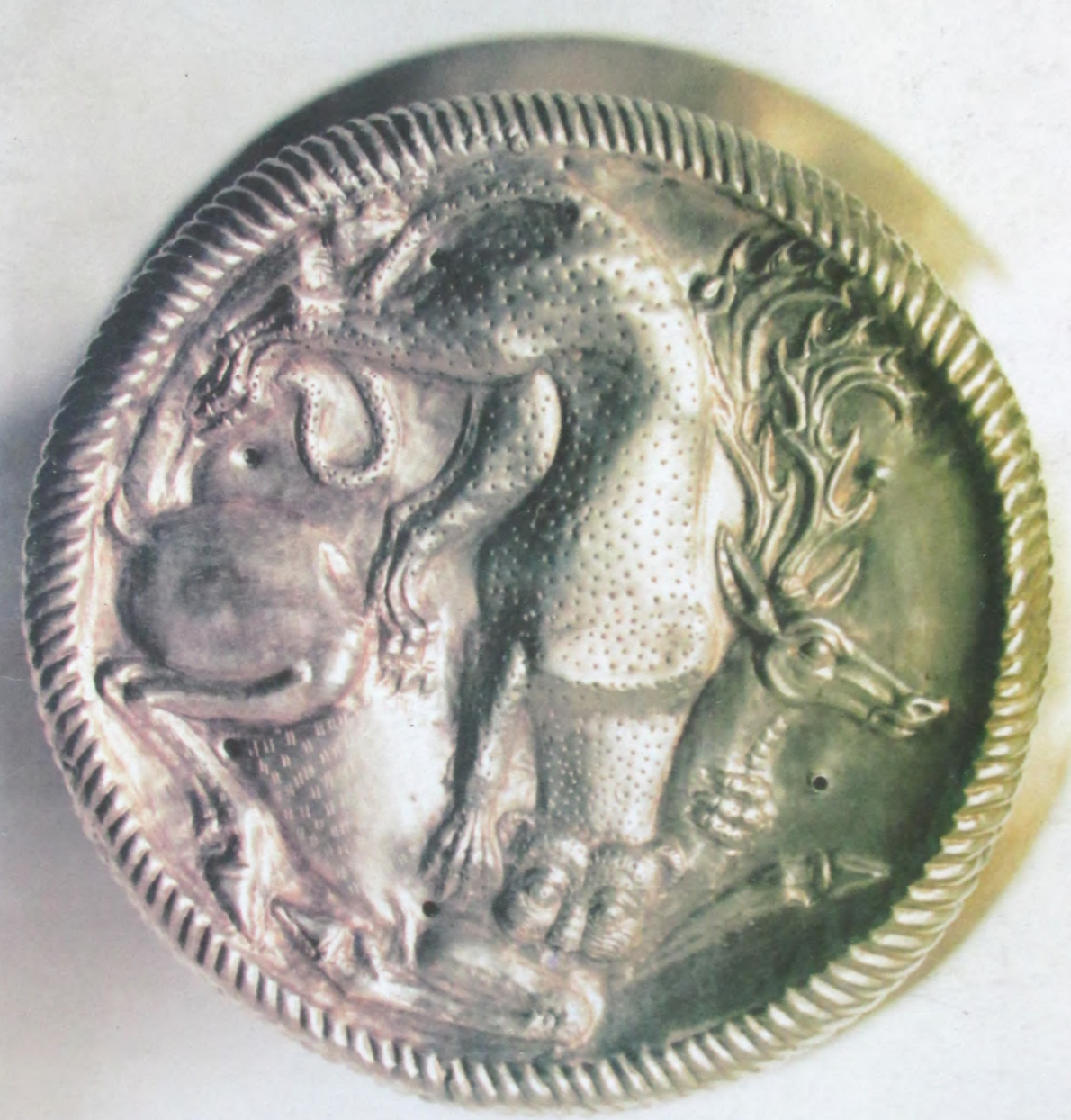

к а т а л о Г

В Ы С Т а В К и

Рис. 1. Обкладинка каталогу виставки «Скарби Південної України» 
УВАЖАЕМЫЕ НИКОЛАЕВЦЫ И ГОСТИ ГОРОДА!

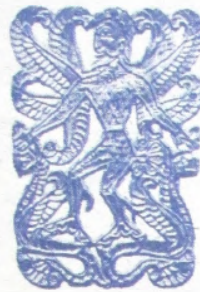

ПРИКОСНИТЕСЬ К СВОЕЙ ИСТОРИИ, УСЛЫШЬТЕ ГОЛОСА ПРЕДКОВ

ПОСЕТИТЕ ВЫСТАВКУ

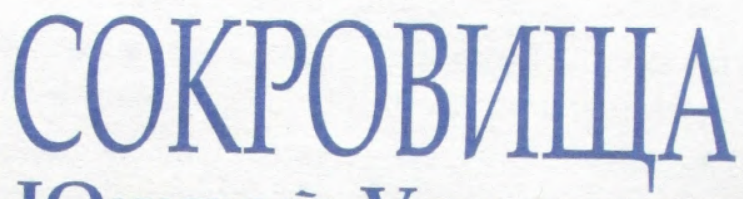

Южной Украины
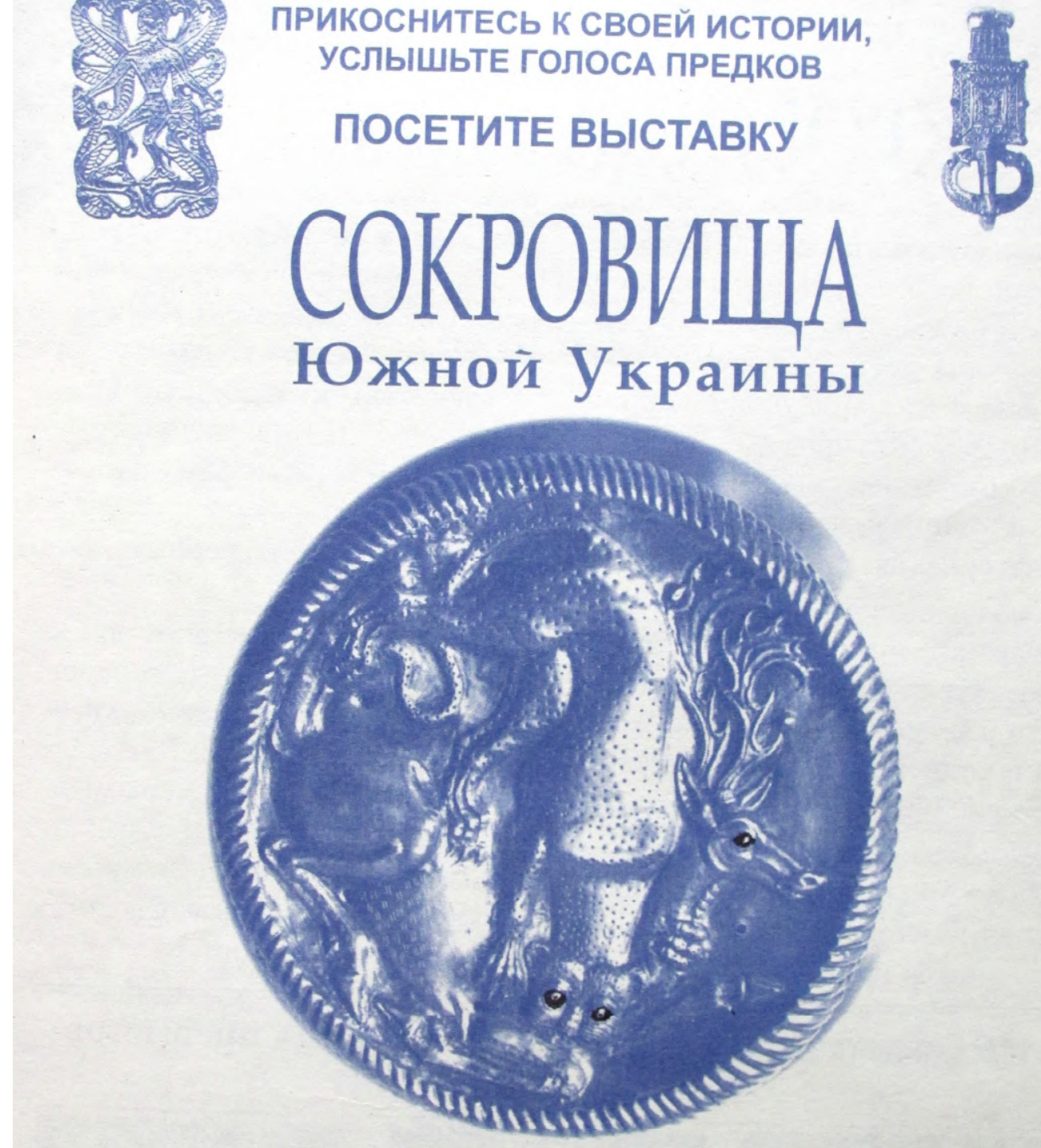

$$
\begin{gathered}
5 \text { октября - } 5 \text { декабря } \\
\text { музей им. В.В.Верещагина, Б.Морская, } 47 \\
\text { ежедневно с } 10.00 \text { до } 18.00
\end{gathered}
$$

740 ПОДЛИННЫХ ЗОЛОТЫХ ИЗДЕЛИЙ,

ЧАСТЬ КОТОРЫХ НАЙДЕНА В НИКОЛАЕВСКОЙ ОБЛАСТИ

ВЫСТАВКА ПРОВОДИЛАСЬ ВО МНОГИХ СТРАНАХ, НО В УКРАИНЕ - ВПЕРВЫЕ!

Рис. 2. Флаєр на газетному папері, який розповсюджували в Миколаєві напередодні відкриття та під час роботи виставки «Скарби Південної України»: 2.1 - лицьова сторона 


\section{ВНИМАНИЕ!}

5 октября - 5 декабря проводится выставка

\section{СОКРОВИЩА Южной Урапны}

Жизнь каждого народа подобна жизни человека. Народы также в муках рождаются, постепенно формируются, достигают зрелости. И, словно люди, даже уйдя в историческое небытие, продолжают жить в потомках. В этом смысле мы являемся наследниками всех наших предшественников.

В основу выставки заложена идея ознакомить николаевцев с историей и культурой древнего и средневекового населения украинской Степи на протяжении огромного отрезка времени - III тыс. до н.э. - XIV в. н.э. Центральное место в экспозиции займут витрины, гле будут представлены материалы ираноязычных кочевников, обитавших на террито- рии Степи в I-м тыс. до н.э. и, прежде всего, скифов. Здесь посетители увидят различные виды вооружения, утварь, детали конской узды, большое количество скифских изделий из золота. Едва ли найдутся равнодушные и возле витрин с расшитыми золотыми украшениями головными уборами и одеждами скифянок.

Один из разделов выставки посвящен культуре античных городов Северного Причерноморья - главным образом, Ольвии. Высокохудожественная греческая керамика, скулыптурные изображения, надписи, высеченные на камне, и многие другие находки занимают достойное место в экспозиции.

\begin{tabular}{|c|c|c|c|c|c|c|c|c|c|c|c|c|c|c|c|c|}
\hline \multirow{2}{*}{\multicolumn{6}{|c|}{$\begin{array}{c}146 \text { комплексов } \\
\text { ОКТЯБРЬ } \\
\end{array}$}} & & \multicolumn{4}{|c|}{$\begin{array}{l}\text { НескоЛЬКО ТЫС } \\
\text { ОТЫХ ВЕЩЕЙ }\end{array}$} & \multicolumn{5}{|c|}{ п предметов } \\
\hline & & & & & & & & 109 & 5PE & & & & HEK & AБP & & \\
\hline$\Pi \mathrm{nH}$ & & 5 & 12 & 19 & 26 & & 2 & 9 & 16 & $23 \quad 30$ & & 7 & 14 & 21 & 28 & Пн \\
\hline BT & & 6 & 13 & 20 & 27 & & 3 & 10 & 17 & 24 & 1 & 8 & 15 & 22 & 29 & BT \\
\hline CP & & 7 & 14 & 21 & 28 & & 4 & 11 & 18 & 25 & 2 & 9 & 16 & 23 & 30 & CP \\
\hline ЧТ & 1 & 8 & 15 & 22 & 29 & & 5 & 12 & 19 & 26 & 3 & 10 & 17 & 24 & 31 & पा \\
\hline חт & 2 & 9 & 16 & 23 & 30 & & 6 & 13 & 20 & 27 & 4 & 11 & 18 & 25 & & חт \\
\hline СБ & 3 & 10 & 17 & 24 & 31 & & 7 & 14 & 21 & 28 & 5 & 12 & 19 & 26 & & СБ \\
\hline $\mathrm{BC}$ & 4 & 11 & 18 & 25 & & 1 & 8 & 15 & 22 & 29 & 6 & 13 & 20 & 27 & & $B C$ \\
\hline
\end{tabular}

\section{ТОЛЬКО ОДИН РАЗ В ЖИЗНИ НАШЕГО ПОКОЛЕНИЯ!}

Рис. 2. Флаєр на газетному папері, який розповсюджували в Миколаєві напередодні відкриття та під час роботи виставки «Скарби Південної України»: 2.2 - зворотній бік 


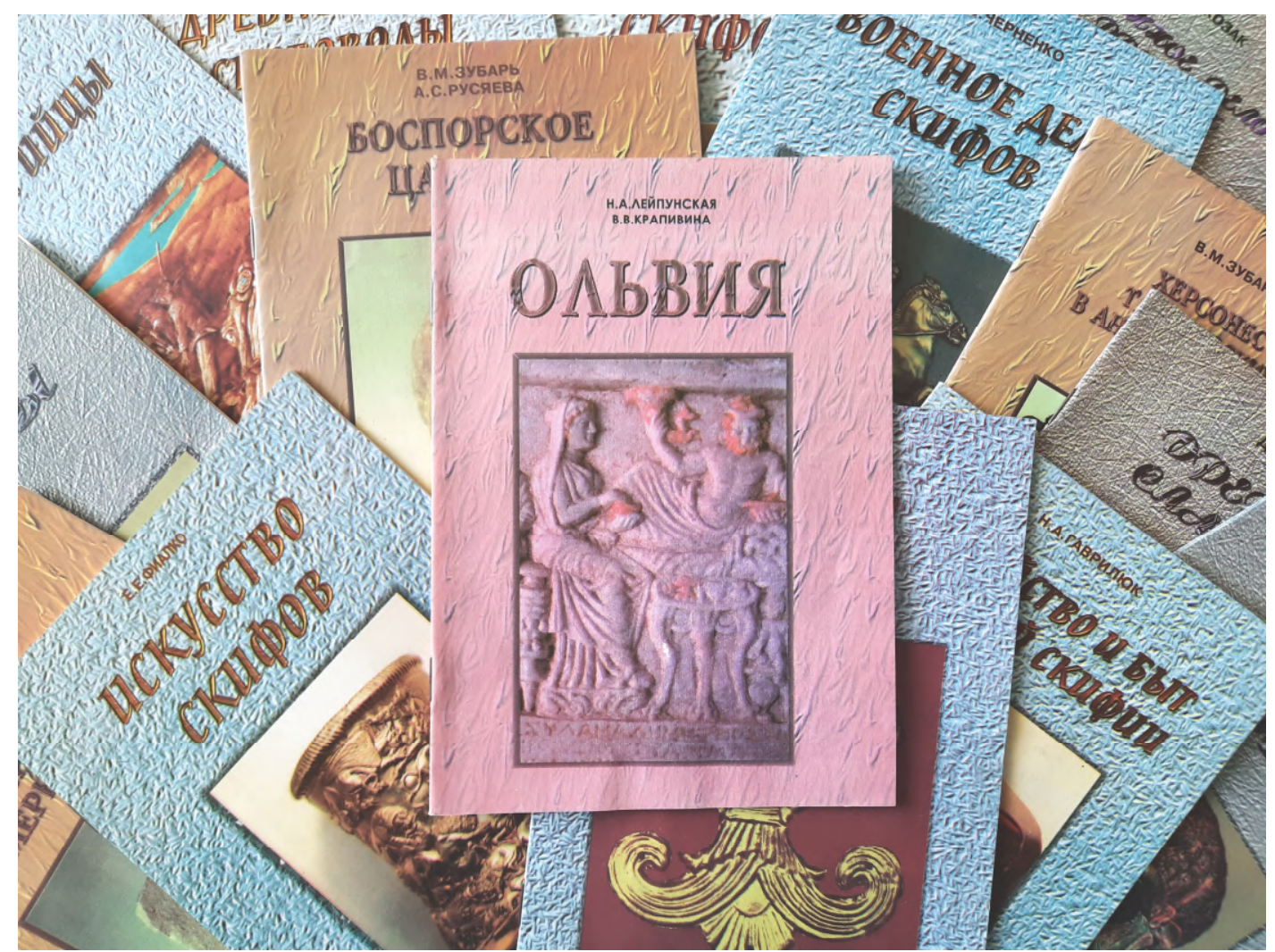

Рис. 3. Обкладинки науково-популярних брошур, що реалізовувалися під час роботи виставки «Скарби Південної України» 
Таблиця 1.

Книги науково-популярної серії «Страницы истории Южной Украины»

\begin{tabular}{|c|c|}
\hline 1. Бунятян Е.Г. & Древнейшие скотоводы украинских степей \\
\hline 2. Махортых С.В. & Киммерийцы \\
\hline 3. Мурзин В.Ю. & История Скифии \\
\hline 4. Черненко Е.В. & Военное дело скифов \\
\hline 5. Гаврилюк Н.А. & Хозяйство и быт Степной Скифии \\
\hline 6. Фиалко Е.Е. & Искусство скифов \\
\hline 7. Бессонова С.С. & Религия скифов \\
\hline 8. Симоненко А.В. & Сарматы в степях Северного Причерноморья \\
\hline 9. Крыжицкий С.Д. & $\begin{array}{l}\text { Античные государства Северного Причер- } \\
\text { номорья }\end{array}$ \\
\hline 10. Русяева А.С. & $\begin{array}{l}\text { Искусство греков Северного Причерноморья } \\
\text { в античную эпоху }\end{array}$ \\
\hline 11. Скржинская М.В. & $\begin{array}{l}\text { Античные писатели о Северном Причерно- } \\
\text { морье }\end{array}$ \\
\hline 12. Самойлова Т.Л. & Античная Тира \\
\hline 13. Назаров В.В. & $\begin{array}{l}\text { Древнегреческое поселение на острове Бе- } \\
\text { резань }\end{array}$ \\
\hline 14. Зубарь В.М., Русяева А.С. & Боспорское царство \\
\hline 15. Зубарь В.М. & Херсонес Таврический в античную эпоху \\
\hline $\begin{array}{l}\text { 16. Лейпунская Н.А., К Крапиви- } \\
\text { на В.В. }\end{array}$ & Ольвия \\
\hline 17. Анохин В.А. & $\begin{array}{l}\text { Античные монеты Северного Причерномо- } \\
\text { рья }\end{array}$ \\
\hline 18. Буйских С.Д. & Античные земледельцы Нижнего Побужья \\
\hline 19. Терпиловский Р.В. & Склавины и анты \\
\hline 20. Козак Д.Н. & Древние славяне \\
\hline 21. Козак Д.Н. & Военное дело древних славян \\
\hline 22. Козак Д.Н. & Готы \\
\hline 23. Козак Д.Н. & Гунны \\
\hline 24. Моця А.П. & Хазары \\
\hline 25. Моця А.П. & $\begin{array}{l}\text { Кочевники Причерноморья на рубеже тыся- } \\
\text { челетий (венгры, печенеги, торки) }\end{array}$ \\
\hline
\end{tabular}

